\title{
DIVERSITY OF TERRESTRIAL FERN SPECIES IN A SUBMONTANE SECONDARY FOREST AT UPPER HANTANA
}

\author{
G.A.D. Perera', I. Withanachchi² \& S.W. Ranasinghe' \\ 'Department of Botany, University of Peradeniya \\ 2 Post Graduate Institute of Ssience, University of Peradeniya
}

Although there are many fern species at the secondary forest of Upper Hantana area, their distribution and the diversity has not been studied adequately. In the Upper Hantana area many of the habitats are under threat due to human activities and therefore, most of these fern species are at a risk. Therefore, it is very important to conserve these fern species and for this purpose, it is necessary to identify all the ferns in the area and their distribution. The objectives of this study were to find out the fern diversity in the Upper Hantana area and to find out microhabitat requirements of these fern species.

Forty-five, $2 \times 4 \mathrm{~cm}^{2}$ quadrates were established at different sites i.e, at the roadside, streamside and in the forest interior of the study site. All the fern species in these quadrates were identified and recorded.

Results revealed that the species, genera and family diversities were high at Upper Hantana area. A total of 29 species belonging to 17 genera and 13 families were recorded from the area. Out of 29 species $53 \%$ were recorded from roadside while $34 \%$ and $17 \%$ were recorded from streamside and forest interior respectively. With respect to the 13 families recorded $48 \%$ were found at roadside, $35 \%$ from the streamside and $17 \%$ from the forest interior.

As there were more fern species at roadside, these may easily be disturbed with increased human activities. 